\title{
Erratum to: Raman spectroscopy of primary bovine aortic endothelial cells: a comparison of single cell and cell cluster analysis
}

\author{
L. L. McManus • A. R. Boyd · G. A. Burke • \\ B. J. Meenan
}

Published online: 13 July 2011

(C) Springer Science+Business Media, LLC 2011

Erratum to: J Mater Sci: Mater Med (2011)

DOI 10.1007/s10856-011-4371-y

The original version of this article unfortunately contained an error in the order of authors. The correct order is given above.

The online version of the original article can be found under doi:10.1007/s10856-011-4371-y.

L. L. McManus · A. R. Boyd ( $\square)$ · G. A. Burke · B. J. Meenan Nanotechnology and Integrated Bioengineering Centre (NIBEC), University of Ulster, Shore Road, Newtownabbey,

Antrim BT37 0QB, Northern Ireland

e-mail: ar.boyd@ulster.ac.uk 